\title{
Management practices, physically effective fiber, and ether extract are related to bulk tank milk de novo fatty acid concentration on Holstein dairy farms
}

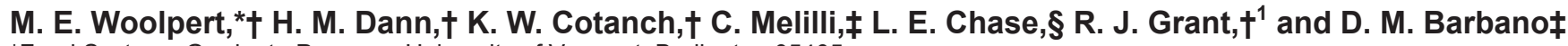 \\ ${ }^{*}$ Food Systems Graduate Program, University of Vermont, Burlington 05405 \\ †William H. Miner Agricultural Research Institute, Chazy, NY 12921 \\ †Department of Food Science, and \\ §Department of Animal Science, Cornell University, Ithaca, NY 14853
}

\section{ABSTRACT}

The objective of this study was to evaluate the relationship of management practices and dietary factors with de novo fatty acid concentration in bulk tank milk from commercial dairy farms milking Holstein cows. Farms were selected based on de novo fatty acid concentration during the 6 mo before the farm visit and were categorized as high de novo (HDN; $24.61 \pm$ $0.75 \mathrm{~g} / 100 \mathrm{~g}$ of fatty acids, mean \pm standard deviation; $\mathrm{n}=19$ ) or low de novo (LDN; $23.10 \pm 0.88 \mathrm{~g} / 100$ $\mathrm{g}$ of fatty acids; $\mathrm{n}=20$ ). Farms were visited once in February, March, or April 2015 and evaluated based on management and facility design known to affect cow behavior, physical and chemical characteristics of the diet, and ration formulation and forage analyses obtained from the farm's nutritionist. We observed no differences between HDN and LDN farms in farm size, time away from the pen for milking, days in milk, or body condition score. We detected no differences between HDN and LDN farms in milk fat or true protein yield; however, milk fat and protein content and de novo fatty acid yield per day were higher for HDN farms, as was gross income per unit of milk sold. High de novo farms tended to be more likely to deliver fresh feed twice versus once per day, have a freestall stocking density $\leq 110 \%$, and provide $\geq 46 \mathrm{~cm}$ of feed bunk space per cow. We observed no detectable differences in forage quality or ration dry matter, crude protein, or starch content. However, ether extract was lower and physically effective neutral detergent fiber was higher for HDN farms. Feeding management, stocking density, dietary ether extract content, and the physical characteristics of the diet are related to de novo fatty acid, fat, and protein concentration in bulk tank milk from high-producing Holstein dairy farms.

Key words: de novo fatty acids, milk fat, milk protein

Received September 26, 2016

Accepted February 12, 2017.

${ }^{1}$ Corresponding author: grant@whminer.com

\section{INTRODUCTION}

De novo milk fatty acids (FA; C4 to C14) are those that are synthesized in the cow's mammary gland using acetate and butyrate - VFA that originate from the fermentation of fibrous feeds in the rumen (Palmquist et al., 1993). Mixed-origin milk fatty acids (C16) can be synthesized in the mammary cells from acetate and butyrate or can enter the mammary secretory cell preformed; at present, no method exists to determine these separately. Preformed FA ( $\geq \mathrm{C} 18)$ enter the mammary cell from the blood stream and originate from the cow's intestinal, liver, or adipose tissues.

A large and systematic change in the fatty acid composition of milk fat occurs with stage of lactation (Lynch et al., 1992); de novo FA start out as low a proportion of total FA in early lactation and increase to a relatively constant concentration when cows are in positive energy balance. In high-producing Holstein cows, de novo FA typically account for 18.2 to $28.4 \%$ of the total FA in milk fat (Jensen, 2002). Factors that affect ruminal conditions, such as nutrition and management, may influence milk fatty acid profiles and are the predominant factors that affect milk de novo fatty acid synthesis among cows of similar breed and stage of lactation (Palmquist et al., 1993; Bauman and Griinari, 2003).

High dietary carbohydrate fermentability and excessive ruminally available PUFA may depress de novo fatty acid synthesis (Harvatine and Bauman, 2011). Dietary fat supplementation may also influence milk fat composition by directly providing substrate for preformed milk FA (Stoffel et al., 2015), although the extent of fatty acid variation may be limited by the melting point of milk fat (Toral et al., 2013). Adequate physically effective NDF (peNDF; 20 to $23 \%$ of ration DM; Mertens, 2002) has been associated with an increase in ruminal pH (Allen, 1997; Kononoff and Heinrichs, 2003) and greater milk fat (Grant et al., 1990) and milk protein content (Caccamo et al., 2014). However, to our knowledge no studies have evaluated 
the relationship between the physical characteristics of the diet and bulk tank de novo FA concentration on commercial Holstein dairy farms.

In addition to the diet, feeding environment may also influence milk composition. For example, stocking density and facility design may influence feeding behaviors such as increasing feeding rate (Collings et al., 2011) or sorting against long particles (Sova et al., 2013), which increase a cow's risk for low ruminal $\mathrm{pH}$ (French and Kennelly, 1990). Management practices and dietary characteristics that result in low ruminal $\mathrm{pH}$ are associated with reduced milk fat content (Allen, 1997) via a shift to the alternate ruminal biohydrogenation pathway, leading to the formation of UFA isomers that downregulate the expression of genes related to de novo FA synthesis (Harvatine and Bauman, 2011).

Previous research has evaluated the relationship between management practices and bulk tank milk de novo FA content for lower-producing, smaller dairy farms that contain a variety of breeds (Woolpert et al., 2016), and it has predicted FA composition using data that describe the source and proportion of forages in the diet (Coppa et al., 2013). However, we need to better understand the relationships among cow management practices, dietary fat content, peNDF, and de novo FA concentration for high-producing Holstein dairy farms. The objectives of this study were to evaluate management practices, dietary chemical composition and physical characteristics, and lactation performance for high-producing Holstein dairy farms with high or low de novo FA concentrations in bulk tank milk. We hypothesized that Holstein dairy farms that optimized cow comfort and fed adequate peNDF would have higher de novo FA concentrations and higher milk fat and protein content in bulk tank milk.

\section{MATERIALS AND METHODS}

\section{On-Farm Data Collection}

Farms were enrolled based on their willingness to participate in the study and the concentration of de novo FA in bulk tank milk samples taken 2 to 20 times per month for each farm over the 6 mo before the the study began. Farms were categorized as high de novo (HDN) or low de novo $(\mathbf{L D N})$ based on their average de novo FA concentration ( $\mathrm{g} / 100 \mathrm{~g}$ of FA) for the 6 mo before the farm visit (September 2014 to February 2015; Table 1). To be eligible to participate in the study, farms needed to be a member of the St. Albans Cooperative Creamery (St. Albans, VT), average at least $25 \mathrm{~kg}$ of milk per cow per day, have $90 \%$ or more Holstein cattle, milk at least 50 cows, and calve yearround. Each farm was visited once between February 25 and April 24, 2015.

Management practices, BCS, and herd demographics were recorded by trained research personnel from Miner Institute (Chazy, NY), working with a farm owner or manager. The primary management factors assessed were stall stocking density, feed bunk space per cow, feeding frequency, feed push-up frequency, time away from pen for milking, and milking frequency.

Diets were sampled for chemical composition analysis as described by Woolpert et al. (2016). Previous research had found no detectable differences in the chemical composition of corn silage or hay crop silage for HDN versus LDN herds (Woolpert et al., 2016), so analysis of these components was omitted from the study. However, the most recent hay crop silage and corn silage analyses were obtained from the farm's nutritional consultant to assess the content of DM, CP,

Table 1. Milk composition data (used to select farms to participate in the study) representing monthly mean milk composition for high de novo $(\mathrm{HDN} ; \mathrm{n}=19)$ and low de novo $(\mathrm{LDN} ; \mathrm{n}=20)$ farms from September 2014 to February 2015

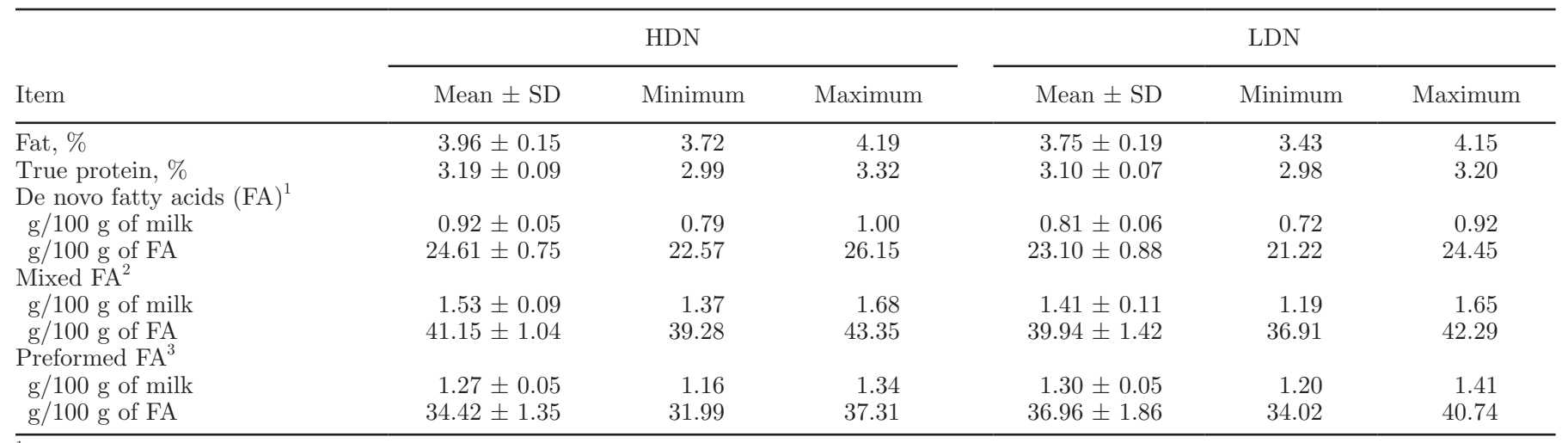

${ }^{1} \mathrm{C} 4$ to $\mathrm{C} 14$.

${ }^{2} \mathrm{C} 16, \mathrm{C} 16: 1$, and $\mathrm{C} 17$.

${ }^{3}$ Greater than or equal to $\mathrm{C} 18$. 
organic-matter-corrected NDF with $\alpha$-amylase and sodium sulfite (aNDFom), ether extract, starch (for corn silage only), and ash as a percentage of DM. Forage analyses were provided by participating nutritionists from 33 farms ( $\mathrm{n}=15 \mathrm{HDN}$; $\mathrm{n}=18 \mathrm{LDN})$.

Total mixed ration samples were collected from 5 to 10 locations along the length of the feed bunk immediately after feed delivery. The TMR samples were mixed manually and subsampled using the quartering technique: mixed samples were divided into 4 equal subsamples. Two subsamples allocated diagonally were remixed and sent to a commercial laboratory for analysis (Dairy One, Ithaca, NY) as described by Woolpert et al. (2016). The TMR samples were analyzed using near infrared spectroscopy with a local algorithm that has been shown to have good to moderate utility to predict $\mathrm{CP}$, aNDFom, $\mathrm{CP}$, starch, and fat content $\left(\mathrm{R}^{2}\right.$ $>0.81$; Berghazi et al., 2000; Mentink et al., 2006).

The remaining 2 subsamples were analyzed separately for particle size distribution on an as-fed basis using the Penn State Particle Separator as described by Heinrichs and Kononoff (2002) and modified to include a 4-mm sieve as reported by Kmicikewycz et al. (2015). Residues on the 3 sieves and the pan were weighed, and the 2 replicates were averaged. The peNDF was calculated by multiplying the proportion of TMR retained on and above the 4-mm sieve by the NDF content of the ration (Kmicikewycz et al., 2015). A weighted average of peNDF based on the number of cows consuming each diet was calculated for each farm. Outliers $(\mathrm{n}=$ 3) were identified and removed from the data set when Cook's D exceeded 0.13.

Ingredients for concentrate feeds included in all diets fed to lactating cows on each farm were requested from the feed companies. Diets were provided by participating nutritionists from 33 farms $(\mathrm{n}=15 \mathrm{HDN} ; \mathrm{n}=18$ LDN). Feed products were categorized based on previous associations with milk fat content or composition as described by Woolpert et al. (2016).

\section{Milk Yield, Composition, and FA Analysis}

Milk yield was determined using the number of cows milking during the farm visit and the average bulk tank milked shipped during the month of the farm visit. Milk composition data were averaged for the month of the farm visit (February, March, or April 2015) and analyzed as reported by Woolpert et al. (2016). In short, milk fat, true protein, and anhydrous lactose percentages were determined using a Fourier transform mid-infrared spectrophotometer (Lactoscope FTA; Delta Instruments, Drachten, the Netherlands) at the St. Albans Cooperative Creamery payment testing laboratory (St. Albans, VT). Calibration for measure- ment of fat, true protein, anhydrous lactose, and FA parameters was done using modified milk calibration samples (Kaylegian et al., 2006) produced monthly. All laboratory mean reference chemistry values were produced by a network of 10 to 12 laboratories for the main components (Wojciechowski et al., 2016), and the reference values for FA composition of the same set of samples were determined as previously described (Wojciechowski and Barbano, 2016).

Milk FA analysis was conducted at the St. Albans Cooperative Creamery payment testing laboratory at the same time as the component milk testing, as described by Woolpert et al. (2016), using partial least squares chemometric prediction models based on the mid-infrared spectra described by Wojciechowski and Barbano (2016).

\section{Statistical Analysis}

Statistical analyses were conducted using SAS (version 9.2; SAS Institute Inc., Cary, NC). Data were summarized by HDN and LDN group and checked for normality using the UNIVARIATE procedure. Data were considered to be normally distributed when the Shapiro-Wilks W was $>0.85$. Differences in management, milk composition, and diet for HDN versus LDN farms were determined using the GLIMMIX procedure. De novo group was the fixed effect and farm was the random effect using the following equation,

$$
Y_{i j}=\mu+\alpha_{i}+R_{j}+E_{i j},
$$

where $Y_{i j}$ is the dependent variable, $\mu$ is the overall mean, $\alpha_{i}$ is the fixed effect of de novo group, $R_{j}$ is the random effect of farm, and $E_{i j}$ is the residual error.

All milk composition and diet composition variables that were normally distributed were tested using a Gaussian distribution with an identity link function. Management data that were not normally distributed were analyzed using an alternative distribution, and the model was checked for overdispersion using the chisquared/degrees of freedom ratio. Models with a ratio close to 1.0 were considered a good model fit (Gbur et al., 2012). The management variables, distributions, and link functions used in the analysis are listed in Table 2. The inclusion of supplements or additives in the concentrate mix was analyzed using a binary distribution and expressed as the percentage of farms in each category, the odds ratio, and the $95 \%$ confidence limit (HDN group was the referent).

A Poisson distribution with a log link function was used to test the number of cows milking on each farm and the number of times feed was pushed up at the feed bunk. A negative binomial distribution with a log 
Table 2. Distributions and link functions used to test variables between high de novo and low de novo herds

\begin{tabular}{lll}
\hline Variable & Distribution & Link function \\
\hline Cows milking, no. & Poisson & Log \\
Time away from pen, h & Gaussian & Identity \\
Feeding frequency & Binary & Logit \\
Freestall & Gaussian & Identity \\
Tiestall & Poisson & Log \\
Push-up frequency & Poisson & Log \\
Freestall & Gaussian & Identity \\
Tiestall & Negative binomial & Log \\
DIM & Gaussian & Identity \\
Feed bunk space, cm/cow & Gaussian & Identity \\
Stocking density, cows/stall & Binary & Logit \\
BCS & Binary & Logit \\
Feed delivery frequency & & \\
Milking frequency & &
\end{tabular}

link function was used to test linear feed bunk space available per cow. Feed delivery frequency ( 1 or 2 times per d), milking frequency (2 or 3 times per $\mathrm{d}$ ), and the inclusion of supplements or additives in the concentrate mix were analyzed using a binary distribution and expressed as the percentage of farms in each category, the odds ratio, and the $95 \%$ confidence limit (HDN group was the referent; Table 2).

Additional analyses were conducted for dietary and management factors by converting interval data into nominal data surrounding a common or industry recommended cut-point (Table 3). The data were then analyzed using the GLIMMIX procedure using a binary distribution and a logit link function and were expressed as the percentage of farms in each category, the odds ratio, and the $95 \%$ confidence limit (HDN group was the referent). Differences were declared significant at $P$ $\leq 0.05$ and trends at $0.05<P \leq 0.10$.

\section{RESULTS AND DISCUSSION}

\section{Farm Characterization and Milk Composition}

A total of 40 farms were visited $(\mathrm{n}=20 \mathrm{HDN}$; $\mathrm{n}=$ $20 \mathrm{LDN}$ ). One HDN farm was removed from the data set due to missing milk composition data, because their milk was shipped to a different processing plant during the month of the farm visit. Therefore, 39 farms ( $=19 \mathrm{HDN} ; \mathrm{n}=20 \mathrm{LDN}$ ) were included in the final analysis.

Milk composition data from the 6 mo before the farm visit are presented in Table 1. Milk FA composition and bulk tank fat and protein tests normally vary across time within a farm. The data in Table 1 represent the average for the HDN and LDN herds across time before the study and were used for general selection and grouping of farms from the St. Albans Coopera-

Table 3. Cut-point and literature used to categorize management characteristics for analysis using odds ratios

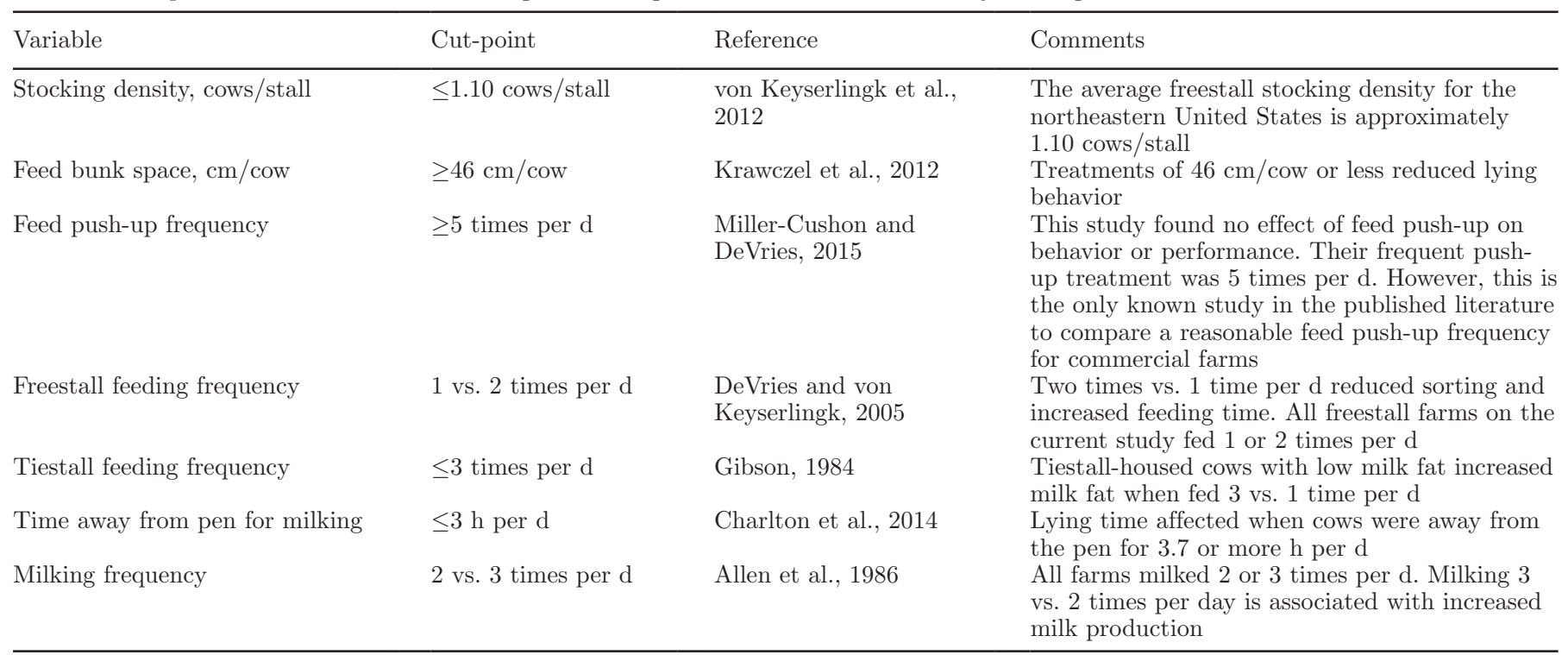


tive (St. Albans, VT) to include in the study. During the months of the study, the milk FA composition may have changed slightly compared with the average from the months before the study. When interpreting milk FA data to improve milk fat and protein production, changes in the relative proportion and output (grams per cow per day) of the groups of FA within a farm across time are used to diagnose the need for management or feeding changes. The real power in the data for routine on-farm management would be to review the changes in values for a farm across time, relating them to milk protein and fat content in the bulk tank milk and to feeding and management changes that caused increases or decreases.

Descriptive statistics, including the frequency of management practices, feeding strategies, and facility designs for HDN and LDN farms are presented in Table 4. We found a similar number of freestall facilities for HDN and LDN herds (16 and 14, respectively) that practiced TMR feeding (18 and 15, respectively), but fewer tiestall facilities ( 3 and 6 , respectively) that practiced component feeding ( 1 and 5 , respectively) for HDN versus LDN herds. The HDN and LDN herds had similar heat abatement (mostly fans), and a variety of freestall feeding systems were used, including post and rail, headlocks, H-bunks, or a combination of these, as well as 3 and 2 rows of stalls per pen.

No differences in milk, fat, and true protein yields were detected between HDN and LDN farms, but milk fat and true protein content were higher $(P<0.01)$ on HDN farms (Table 5). This positive relationship between de novo FA and milk fat and true protein

Table 4. Description of management practices and facility design (number of farms) between high de novo (HDN) and low de novo (LDN) commercial dairy farms

\begin{tabular}{lrr}
\hline Item & HDN & LDN \\
\hline Farms enrolled & 20 & 20 \\
Farms in final data set & 19 & 20 \\
Freestall facility & 16 & 14 \\
2 Rows per pen & 5 & 1 \\
3 Rows per pen & 11 & 13 \\
Tiestall facility & 3 & 6 \\
Certified organic & 0 & 1 \\
Component feeding & 1 & 5 \\
TMR feeding & 18 & 15 \\
Uses test-day program $^{1}$ & 8 & 11 \\
Computer management & 12 & 14 \\
Fans over stalls & 14 & 12 \\
Fans over feed bunk & 5 & 5 \\
Freestall feeding system & & \\
Post and rail & 7 & 5 \\
H-bunk & 6 & 1 \\
Headlocks & 1 & 3 \\
Combination & 2 & 5
\end{tabular}

${ }^{1}$ Dairy Herd Improvement Association (Vermont DHIA, White River Junction, VT; Dairy One, Ithaca, NY). percentage agreed with the results of Barbano et al. (2014), who evaluated bulk tank milk composition on over 400 commercial dairy farms. De novo FA expressed as $\mathrm{g} / 100 \mathrm{~g}$ of $\mathrm{FA}$ and as $\mathrm{g} / 100 \mathrm{~g}$ of milk were higher $(P$ $<0.01$ ) on HDN farms, and preformed FA expressed as $\mathrm{g} / 100 \mathrm{~g}$ of $\mathrm{FA}$ and as $\mathrm{g} / 100 \mathrm{~g}$ of milk were lower $(P<0.01$ and $P=0.02$, respectively) on HDN farms. These results were consistent with previous research indicating that HDN farms had higher milk fat and true protein content in bulk tank milk (Woolpert et al., 2016). De novo FA yield, expressed as g/d, was higher $(P<0.01)$ for HDN farms, but we detected no difference detected in milk yield $(P=0.91)$, suggesting that cows on HDN farms synthesized more de novo FA. However, milk weights per cow were not measured directly; instead, they were estimated indirectly based on the number of cows milking on the day of the farm visit and the average bulk tank milk shipped per day during the month of the farm visit. Thus, the uncertainty in the milk weight data is higher than that for the milk composition data. Further research is needed under conditions in which milk weight per cow per day can be accurately measured, along with milk composition, to determine whether greater de novo FA synthesis is always associated with greater milk fat and true protein yields.

The difference in income per cow between the HDN and LDN herds would depend on the actual milk price at a given point in time. The average fat and protein price for Federal Milk Order No. 1 for February through April 2015 (US Department of Agriculture, 2015) was $\$ 4.19$ and $\$ 5.74$ per $\mathrm{kg}$, respectively. Therefore, at $30 \mathrm{~kg}$ of milk per cow per day, the average HDN farm earned a gross of $\$ 5.00$ and $\$ 5.49$ per cow for fat and protein, respectively. The average LDN farm at $30 \mathrm{~kg}$ of milk per cow per day earned a gross of $\$ 4.75$ and $\$ 5.30$ per cow for fat and protein, respectively. These differences for fat and true protein between HDN and LDN herds at $30 \mathrm{~kg}$ of milk would result in gross income differences of $\$ 9,125$ for fat and $\$ 6,935$ for true protein per 100 milking cows per year.

An individual cow's FA profile varies throughout her lactation (Lynch et al., 1992; Palmquist et al., 1993). However, no differences were observed in the number of cows milking or the average DIM between HDN and LDN farms (Table 6; $P=0.74$ and 0.61 , respectively). Therefore, the observed differences in de novo synthesis in this study were unlikely to be caused by differences in stage of lactation between HDN and LDN farms.

\section{Herd Management Practices}

Feed bunk space (measured in linear centimeters per cow) tended to be higher on HDN farms (Table 6; $P$ 
Table 5. Least squares means of milk composition factors for high de novo (HDN; $\mathrm{n}=19$ ) and low de novo $(\mathrm{LDN} ; \mathrm{n}=20)$ farms for the month of the farm visit

\begin{tabular}{lcccr}
\hline Item & HDN & LDN & SEM & $P$-value \\
\hline Milk yield, kg/d & 31.9 & 32.1 & 0.9 & 0.91 \\
Fat, \% & 3.98 & 3.78 & 0.04 & $<0.01$ \\
Fat, kg/d & 1.27 & 1.21 & 0.03 & 0.25 \\
De novo fatty acids (FA) ${ }^{1}$ & & & & \\
g/100 g of milk & 0.99 & 0.86 & 0.01 & $<0.01$ \\
g/100 g of FA & 25.99 & 23.78 & 0.22 & $<0.01$ \\
g/d & 315.6 & 276.2 & 9.5 & $<0.01$ \\
Mixed FA ${ }^{2}$ & & & & $<0.01$ \\
g/100 g of milk & 1.48 & 1.35 & 0.02 & $<0.01$ \\
g/100 g of FA & 38.86 & 37.36 & 0.37 & 0.08 \\
g/d & 472.0 & 434.2 & 15.2 & 0.02 \\
Preformed FA & & & 0.02 & $<.17$ \\
g/100 g of milk & 1.32 & 1.38 & 0.50 & $<0.01$ \\
g/100 g of FA & 34.60 & 38.21 & 10.4 & 0.44 \\
g/d & 419.0 & 439.3 & 0.02 & 0.25 \\
True protein, \% & 3.19 & 3.08 & 0.03 & 0.66 \\
True protein, kg/d & 1.02 & 0.99 & 0.5 & \\
MUN, mg/dL & 12.1 & 12.9 & 0.02 & \\
Anhydrous lactose, \% & 4.65 & 4.66 & & \\
Anhydrous lactose, kg/d & 1.46 & 1.51 & 0.05 & \\
\hline${ }^{1}$ C4 to C14. & & & & \\
${ }^{2}$ C16, C16:1, and C17. & & & & \\
${ }^{3}$ Greater than or equal to C18. & & & & \\
& & & & \\
\end{tabular}

$=0.06)$. When categorized as above or below $46 \mathrm{~cm}$ of space per cow, HDN herds tended $(P=0.06)$ to be 10 times more likely to provide at least $46 \mathrm{~cm}$ of feed bunk space (Table 7). Krawczel et al. (2012) found no effect of feed bunk space on milk fat percentage or milk composition, but that was a short-term study (14 d periods), unlike the present study, in which bulk tank milk would reflect longer-term responses to stocking density. Additionally, mean feed bunk space for LDN farms for the current study was $39.8 \mathrm{~cm}$ per cow, which was more overcrowded than the highest feed bunk stocking density treatment in the Krawczel et al. (2012) study. Other research has reported that a decrease of $10 \mathrm{~cm} /$ cow in feed bunk space is associated with a reduction of 0.06 percentage points in milk fat content (Sova et al. 2013). Commonly observed changes in feeding behavior with decreased feed bunk space (i.e., greater rate of eating, fewer and larger meals) predispose the cow to lower ruminal $\mathrm{pH}$ that may alter FA biohydrogenation pathways and result in depressed de novo FA synthesis (Grant and Albright, 2001; Harvatine and Bauman, 2011; Campbell et al., 2015).

We detected no difference in overall stall stocking density (Table 6; $P=0.41$ ), but HDN farms tended to be 4.7 times more likely to have a stocking density $\leq 1.10$ cows per stall (Table $7 ; P=0.08$ ). Most freestall

Table 6. Least squares means of management data for high de novo (HDN; $n=19)$ and low de novo (LDN; $\mathrm{n}=20$ ) farms

\begin{tabular}{|c|c|c|c|c|}
\hline Item & HDN & LDN & SEM & $P$-value \\
\hline Cows milking, no. & 190 & 211 & 46 & 0.74 \\
\hline Time away from pen, $h^{1}$ & 3.5 & 3.3 & 0.4 & 0.71 \\
\hline Tiestall feeding frequency & 3.3 & 4.1 & 1.1 & 0.57 \\
\hline \multicolumn{5}{|l|}{ Push-up frequency } \\
\hline Tiestall & 4.9 & 6.1 & 1.4 & 0.88 \\
\hline Freestall $^{2}$ & 1.6 & 1.8 & 0.9 & 0.32 \\
\hline DIM & 170 & 176 & 8 & 0.61 \\
\hline Feed bunk space, ${ }^{3} \mathrm{~cm} / \mathrm{cow}$ & 50.0 & 39.8 & 3.7 & 0.06 \\
\hline Stocking density, ${ }^{3}$ cows /stall & 1.11 & 1.16 & 0.04 & 0.41 \\
\hline $\mathrm{BCS}$ & 3.05 & 3.03 & 0.02 & 0.65 \\
\hline
\end{tabular}

${ }^{1}$ Includes only freestall farms with a designated holding area $(n=16$ HDN; $n=14$ LDN).

${ }^{2}$ Freestall bunks included post and rail, headlocks, and H-bunks. For freestall push-up frequency, farms with H-bunks $(\mathrm{n}=6 \mathrm{HDN} ; \mathrm{n}=1 \mathrm{LDN})$ were not included in the analysis, because feed cannot be pushed up in an H-bunk.

${ }^{3}$ Freestall only $(\mathrm{n}=16 \mathrm{HDN} ; \mathrm{n}=14 \mathrm{LDN})$. 
Table 7. Effects of milking and freestall feeding frequency on bulk tank milk fatty acid composition among high de novo (HDN) or low de novo (LDN) farms

\begin{tabular}{|c|c|c|c|c|}
\hline Item & $\mathrm{HDN}, \%$ & $\mathrm{LDN}, \%$ & $\mathrm{OR}^{1}(95 \% \mathrm{CI})$ & $P$-value \\
\hline Time away from pen $\leq 3 \mathrm{~h} / \mathrm{d}^{3}$ & 78.72 & 75.15 & $1.22(0.16-9.12)$ & 0.84 \\
\hline Stall stocking density $\leq 1.10$ cows $/$ stall $^{6}$ & 65.29 & 21.35 & $4.74(0.83-27.21)$ & 0.08 \\
\hline Feed bunk space $\geq 46 \mathrm{~cm}$ per $\mathrm{cow}^{7}$ & 43.71 & 7.12 & $10.13(0.91-112.41)$ & 0.06 \\
\hline Tiestall feeding frequency ${ }^{8}$ & 67.38 & 42.51 & $2.79(0.06-134.62)$ & 0.56 \\
\hline
\end{tabular}

${ }^{1} \mathrm{OR}=$ odds ratio. The HDN group was set as the referent.

${ }^{2}$ Percent of farms that milked twice per day.

${ }^{3}$ Percent of freestall farms that removed the cows for 3 or more hours per day for milking. Farms that allowed access to the freestall pen during milking were excluded from the analysis.

${ }^{4}$ Percent of farms that fed twice per day.

${ }^{5}$ Percent of freestall farms that pushed up the feed 5 or more times per day. Farms with H-bunk mangers were excluded from the analysis.

${ }^{6}$ Percent of freestall farms with freestall stocking density at 1.10 cows per stall or less.

${ }^{7}$ Percent of freestall farms with less than $46 \mathrm{~cm}$ of feed bunk space per cow.

${ }^{8}$ Percent of tiestall farms feeding 3 times per $\mathrm{d}$ or less.

facilities in the northeastern United States have more rows of freestalls than the corresponding amount of bunk space per cow, and have a stocking density of approximately 1.10 cows per stall (von Keyserlingk et al., 2012). The results of the current study were consistent with the observations of Woolpert et al. (2016), who found that higher stocking density was related to lower de novo FA content in bulk tank milk.

We detected no difference in tiestall feeding frequency $(P=0.56)$. However, HDN freestall farms tended to be 5 times more likely to feed cows twice versus once per day (Table $7 ; P=0.07$ ). Previous research to evaluate feed management and milk FA found no detectable difference in freestall feeding frequency, but an increase in tiestall feeding frequency for HDN compared with LDN herds (Woolpert et al., 2016). Sova et al. (2013) found that freestall-housed cows on commercial farms fed twice versus once per day decreased sorting against long particles, and increased DMI, milk yield, eating time, and rumination time. Rottman et al. (2014) reported an increase in milk fat content when cows were fed 4 times versus 1 time per day. The results of the present study suggest that the increase in milk fat content observed by Sova et al. (2013) and Rottman et al. (2014) may have been due to an increase in de novo FA synthesis.

We detected no differences in the overall mean of feed push-up frequency between HDN and LDN herds (Table $6 ; P=0.88$ and $P=0.32$ for tiestall and freestall herds, respectively). However, HDN farms were less likely to push up the feed when the cut-point of pushing up the feed 5 or more times per day was used for analysis (Table 7; $P=0.05$ ). Typically, pushing up the feed allows the cow greater access, and has been associated with increased milk yield and feed efficiency
(Armstrong et al., 2008). However, previous research has also indicated that fresh feed delivery motivates cows to eat more effectively than simply pushing up the feed (DeVries et al., 2003; DeVries and von Keyserlingk, 2005). The LDN freestall herds may have pushed up the feed more often because they fed the cows less frequently.

Very little research has evaluated the effects of feed push-up frequency on behavior or lactation performance. Armstrong et al. (2008) reported an increase in milk yield and feed efficiency when feed was pushed up every $30 \mathrm{~min}$ for the first $2 \mathrm{~h}$ after feeding, compared with 1 time per hour in the first $2 \mathrm{~h}$ after feeding. However, Miller-Cushon and DeVries (2015) reported no difference in behavior or lactation performance when comparing a push-up frequency of 3 versus 5 times per d. Future research is needed to better understand the effects of feed delivery and feed push-up frequency on rumen fermentation and milk fat composition.

\section{Dietary Strategies}

We detected no differences in dietary DM, CP, ADF, NDF, or starch, but ether extract in the TMR was lower $(P<0.01)$ on HDN farms $(3.7$ vs. $4.0 \%$ of DM for HDN and LDN farms, respectively; Table 8). Although we found no significant differences between HDN and LDN herds in the amount of dietary NDF or starch, differences in the fermentability of starch or NDF sources could have existed, but we did not measure this. Future research should assess potential differences in carbohydrate fermentability between diets fed to HDN and LDN herds.

Still, these results were consistent with previous research evaluating dietary chemical composition on 
Table 8. Least squares means of dietary chemical composition for diets from high de novo (HDN) and low de novo (LDN) farms

\begin{tabular}{lrrrr}
\hline Item & HDN & LDN & SEM & $P$-value \\
\hline DM, \% & 41.7 & 43.7 & 1.3 & 0.23 \\
CP, \% of DM & 15.6 & 16.2 & 0.4 & 0.29 \\
aNDFom, \% of DM & 37.8 & 35.4 & 1.0 & 0.20 \\
Ether extract, \% of DM & 3.7 & 4.0 & 0.1 & $<0.01$ \\
Starch, \% of DM & 22.6 & 24.3 & 1.2 & 0.29 \\
\hline
\end{tabular}

${ }^{1}$ Data were mathematically composited by the number of cows that consumed the diet, and analyzed using farm as the experimental unit.

${ }^{2}$ Organic-matter-corrected NDF with $\alpha$-amylase and sodium sulfite.

Table 9. Least squares means of particle size distribution using the Penn State Particle Separator for diets from high de novo (HDN) and low de novo (LDN) farms

\begin{tabular}{lcccc}
\hline Item & HDN & LDN & SEM & $P$-value \\
\hline peNDF, ${ }^{1} \%$ of DM & 26.8 & 21.4 & 1.1 & $<0.01$ \\
19-mm sieve, \% as fed & 16.5 & 11.6 & 2.7 & 0.18 \\
8-mm sieve, \% as fed & 38.6 & 38.4 & 1.9 & 0.92 \\
4-mm sieve, \% as fed & 16.4 & 11.8 & 1.4 & 0.02 \\
Pan, \% as fed & 28.5 & 38.2 & 2.2 & $<0.01$ \\
\hline
\end{tabular}

${ }^{1}$ peNDF $=$ physically effective NDF.

Table 10. Grain ingredient inclusion from high de novo $(\mathrm{HDN} ; \mathrm{n}=15)$ and low de novo $(\mathrm{LDN} ; \mathrm{n}=18)$ farms

\begin{tabular}{lcccc}
\hline Item & HDN, $\%$ & LDN, $\%$ & OR $^{1}(95 \%$ CI $)$ & $P$-value \\
\hline Tallow $^{2}$ & 24.91 & 35.22 & $0.61(0.10-3.63)$ & 0.57 \\
Rumen inert fat $_{\text {Monensin }}^{3}$ & 50.00 & 70.68 & $0.41(0.08-2.23)$ & 0.29 \\
Yeast & 75.09 & 58.87 & $2.11(0.36-12.29)$ & 0.39 \\
Animal-derived protein & 33.25 & 29.32 & $1.20(0.21-6.80)$ & 0.83 \\
Rumen-protected amino acid & 33.23 & 23.42 & $1.63(0.27-9.75)$ & 0.58 \\
Dried distillers grain & 41.61 & 23.43 & $2.33(0.41-13.40)$ & 0.33 \\
\hline
\end{tabular}

${ }^{1} \mathrm{OR}=$ odds ratio. The HDN group was set as the referent.

${ }^{2}$ Percentage of farms feeding product.

${ }^{3}$ Rumensin (Elanco Animal Health, Indianapolis, IN).

Table 11. Least squares means of corn silage analysis provided by farms' nutritionists for high de novo (HDN) and low de novo (LDN) farms

\begin{tabular}{|c|c|c|c|c|c|}
\hline Item & $\mathrm{n}$ & HDN & LDN & SEM & $P$-value \\
\hline \multicolumn{6}{|l|}{ Corn silage } \\
\hline DM, \% & 23 & 29.5 & 32.3 & 1.3 & 0.11 \\
\hline $\mathrm{CP}, \%$ of $\mathrm{DM}$ & 22 & 8.5 & 8.0 & 0.2 & 0.10 \\
\hline aNDFom, ${ }^{1} \%$ of DM & 10 & 43.2 & 42.6 & 1.9 & 0.83 \\
\hline Ether extract, \% of DM & 20 & 3.1 & 3.1 & 0.1 & 0.88 \\
\hline Starch, \% of DM & 20 & 27.7 & 31.9 & 1.9 & 0.11 \\
\hline Ash, \% of DM & 20 & 3.7 & 3.6 & 0.2 & 0.57 \\
\hline \multicolumn{6}{|l|}{ Hay crop silage } \\
\hline DM, \% & 24 & 33.3 & 42.8 & 2.8 & 0.02 \\
\hline $\mathrm{CP}, \%$ of $\mathrm{DM}$ & 23 & 17.3 & 16.5 & 0.7 & 0.37 \\
\hline aNDFom, $\%$ of DM & 12 & 50.2 & 48.4 & 3.3 & 0.69 \\
\hline Ether extract, \% of DM & 21 & 4.1 & 3.7 & 0.2 & 0.12 \\
\hline Starch, \% of DM & 18 & 1.7 & 1.7 & 0.3 & 0.99 \\
\hline Ash, $\%$ of DM & 21 & 10.5 & 9.6 & 0.7 & 0.32 \\
\hline
\end{tabular}

${ }^{1}$ Organic-matter-corrected NDF with $\alpha$-amylase and sodium sulfite. 
HDN and LDN farms (Woolpert et al., 2016). High amounts of dietary fat are a risk factor for milk fat depression, and diets with a FA content as low as $3 \%$ of DM can reduce milk fat content and de novo FA yield when free oils rich in linoleic acid are fed (Stoffel et al., 2015). Future research should consider FA profiles in addition to dietary ether extract content and rate of free fat release from the feed in the rumen to better understand the effect of the ration on lactation performance and milk fat composition.

Physically effective NDF was higher for TMR fed to cows on HDN farms (Table 9; $P<0.01$ ). Caccamo et al. (2014) found no changes in milk fat or milk yield, but did find an increase in milk true protein content for commercial dairy farms that fed adequate peNDF. Mertens (2002) recommended a minimum peNDF of approximately $21 \%$ of DM to avoid milk fat depression; the peNDF for HDN herds in the present study was $26.8 \%$ - associated with the highest levels of milk de novo FA.

We detected no difference in the inclusion of feed products (Table 10; $P>0.10$ ) or chemical composition of hay crop silage or corn silage (Table $11 ; P>0.10$ ) included in the lactating diets, except for DM percentage (33.3 and $42.8 \%$ for HDN and LDN farms, respectively). A study of grass silages from commercial dairy farms indicated that hay crop silage of $34 \%$ of DM is optimal for silage fermentation (O'Brien et al., 2007) and results in the highest quality of silage. The silage DM content for the HDN farms most closely resembled this optimal DM content.

\section{CONCLUSIONS}

We related management and dietary practices that affect cow behavior and rumen conditions to de novo FA concentrations in bulk tank milk on Holstein dairy farms. At a constant level of milk production, the gross income per unit of milk produced was higher on the high de novo farms because of higher milk fat and true protein concentrations. Management (i.e., frequent feed delivery and increased feed bunk space per cow) and dietary (i.e., adequate physically effective fiber and lower ether extract) factors that differed between HDN and LDN farms have been shown in earlier studies to affect ruminal function. Therefore, the de novo FA concentration of bulk tank milk may be an important tool for monitoring ruminal function on commercial dairy farms. Its routine use for on-farm management would involve tracking changes in the values for the same farm across time and relating the values milk protein and fat content in the bulk tank milk, as well as associated feeding and management changes. However, the present study was correlational in nature and does not imply a causal relationship. Future research is needed to evaluate whether a change in one or more of the management or nutritional strategies identified in the current study causes an increase in de novo FA synthesis and milk fat and true protein content on commercial dairy farms.

\section{ACKNOWLEDGMENTS}

The authors thank the laboratory and field staff of St. Albans Cooperative Creamery (St. Albans, VT) for their technical assistance in milk analysis and farm visits. In addition, the authors are grateful for the assistance of the farms that participated in this study. The technical support of Evert De Jong and Wopke Boekema of Delta Instruments (Drachten, the Netherlands) was important for this study. The laboratory analysis support for milk reference chemistry by Sara Bova, Michelle Bilotta, and Chassidy Coon (Cornell University, Department of Food Science, Ithaca, NY) is greatly appreciated, as is the support from the Miner Institute (Chazy, NY) research staff.

\section{REFERENCES}

Allen, D. B., E. J. DePeters, and R. C. Laben. 1986. Three times a day milking: Effects on milk production, reproductive efficiency, and udder health. J. Dairy Sci. 69:1441-1446.

Allen, M. S. 1997. Relationship between fermentation acid production in the rumen and the requirement for physically effective fiber. J. Dairy Sci. 80:1447-1462.

Armstrong, D. V., T. R. Bilby, W. Wuthironarith, W. Stathonghon, and S. Runkraung. 2008. Effect of different feed push-up schedule on milk production, feed intake, and behavior in Holstein dairy cows. J. Dairy Sci. 91(E Suppl. 1):253. (Abstr.)

Barbano, D. M., C. Melilli, and T. R. Overton. 2014. Advanced use of FTIR spectra of milk for feeding and health management. Page 105-113 in Proc. Cornell Nutrition Conf., Syracuse, NY. Published by Cornell University, Department of Animal Science, Ithaca, NY.

Bauman, D. E., and J. M. Griinari. 2003. Nutritional regulation of milk fat synthesis. Annu. Rev. Nutr. 23:203-227.

Berghazi, P., J. S. Shenk, and M. O. Westerhaus. 2000. LOCAL prediction with near infrared multi-purpose databases. J. Near Infrared Spectrosc. 8:1-9.

Caccamo, M., J. D. Ferguson, R. F. Veerkamp, I. Schadt, P. Petriglieri, G. Azzaro, A. Pozzebon, and G. Licitra. 2014. Association of total mixed ration particle fractions retained on the Penn State Particle Separator with milk, fat, and protein yield lactation curves at the cow level. J. Dairy Sci. 97:2502-2511.

Campbell, M. A., K. W. Cotanch, C. S. Ballard, H. M. Dann, D. M. Barbano, A. M. Couse, and R. J. Grant. 2015. Effects of stocking density and source of forage fiber on short-term behavioral and lactational responses of Holstein dairy cows. J. Dairy Sci. 98(E Suppl. 2):18. (Abstr.)

Charlton, G. L., D. B. Haley, J. Rushen, and A. M. de Passillé. 2014. Stocking density, milking duration, and lying times of lactating cows on Canadian freestall dairy farms. J. Dairy Sci. 97:2694-2700.

Collings, L. K. M., D. M. Weary, N. Chapinal, and M. A. G. von Keyserlingk. 2011. Temporal feed restriction and overstocking increase competition for feed by dairy cattle. J. Dairy Sci. 94:5480-5486.

Coppa, M., A. Ferlay, C. Chassaing, C. Agabriel, F. Glasser, Y. Chilliard, G. Borreani, T. Baars, D. Kusche, O. M. Harstad, J. Verbic, J. Golecký, and B. Marin. 2013. Prediction of bulk milk fatty acid 
composition based on farming practices collected through on-farm surveys. J. Dairy Sci. 96:4197-4211.

DeVries, T. J., and M. A. G. von Keyserlingk. 2005. Time of feed delivery affects the feeding and lying patterns of dairy cows. J. Dairy Sci. 88:625-631.

DeVries, T. J., M. A. G. von Keyserlingk, and K. A. Beauchemin. 2003. Short communication: Diurnal feeding pattern of lactating dairy cows. J. Dairy Sci. 86:4079-4082.

French, N., and J. J. Kennelly. 1990. Effects of feeding frequency on ruminal parameters, plasma insulin, milk yield, and milk composition in Holstein cows. J. Dairy Sci. 73:1857-1863.

Gbur, E. E., W. W. Stroup, K. S. McCarter, D. Durham, L. J. Young, M. Christman, M. West, and M. Kramer. 2012. Generalized linear mixed models. Pages 109-184 in Analysis of Generalized Linear Mixed Models in the Agricultural and Natural Resources Sciences. American Society of Agronomy, Madison. WI.

Gibson, J. P. 1984. The effects of frequency of feeding on milk production of dairy cattle: An analysis of published results. Anim. Prod. $38: 181-189$.

Grant, R. J., and J. L. Albright. 2001. Effect of animal grouping on feeding behavior and intake of cattle. J. Dairy Sci. 84(E Suppl.):E156-E163.

Grant, R. J., V. F. Colenbrander, and D. R. Mertens. 1990. Milk fat depression in dairy cows: Role of silage particle size. J. Dairy Sci. $73: 1834-1842$

Harvatine, K. J., and D. E. Bauman. 2011. Characterization of the acute lactational response to trans-10, cis-12 conjugated linoleic acid. J. Dairy Sci. 94:6047-6056.

Heinrichs, A. J., and P. J. Kononoff. 2002. Evaluating particle size of forages and TMRs using the new Penn State Forage Particle Separator. Technical Bulletin, College of Agriculture Science, Cooperative Extension. DAS 02-42. Accessed Mar. 23, 2017. http://people.vetmed.wsu.edu/jmgay/courses/documents/DAS02421.pdf.

Jensen, R. G. 2002. The composition of bovine milk lipids: January 1995 to December 2000. J. Dairy Sci. 85:295-350.

Kaylegian, K. E., G. E. Houghton, J. M. Lynch, J. R. Fleming, and D. M. Barbano. 2006. Calibration of infrared milk analyzers: Modified milk versus producer milk. J. Dairy Sci. 89:2817-2832.

Kmicikewycz, A. D., K. J. Harvatine, and A. J. Heinrichs. 2015. Effects of corn silage particle size, supplemental hay, and forage-toconcentrate ration on rumen $\mathrm{pH}$, feed preference, and milk fat profile of dairy cattle. J. Dairy Sci. 98:4850-4868.

Kononoff, P. J., and A. J. Heinrichs. 2003. The effect of reducing alfalfa haylage particle size on cows in early lactation. J. Dairy Sci. 86:1445-1457.

Krawczel, P. D., L. B. Klaiber, R. E. Butzler, L. M. Klaiber, H. M. Dann, C. S. Mooney, and R. J. Grant. 2012. Short-term increases in stocking density affect the lying and social behavior, but not the productivity, of lactating Holstein dairy cows. J. Dairy Sci. 95:4298-4308

Lynch, J. M., D. M. Barbano, D. E. Bauman, G. F. Hartnell, and M. A. Nemeth. 1992. Effect of a prolonged release formulation of $\mathrm{N}$ methionyl bovine somatotropin (sometribove) on production and composition of milk fat. J. Dairy Sci. 75:1794-1809.
Mentink, R. L., P. C. Hoffman, and L. M. Bauman. 2006. Utility of near-infrared reflectance spectroscopy to predict nutrient composition and in vitro digestibility of total mixed rations. J. Dairy Sci. 89:2320-2326.

Mertens, D. R. 2002. Determination of Starch in Large Particles. RoTap Shaker Method. U.S. Dairy Forage Research Center, Madison, WI. (Rev. April 2002).

Miller-Cushon, E. K., and T. J. DeVries. 2015. Associations between feed push-up frequency, lying and feeding behavior, and milk composition of dairy cows. J. Dairy Sci. 98(E Suppl 2):13. (Abstr.)

O'Brien, M., P. O. Keily, P. D. Forristal, and H. T. Fuller. 2007. Visible fungal growth on baled grass silage during the winter feeding season in Ireland and silage characteristics associated with the occurrence of fungi. Anim. Feed Sci. Technol. 139:234-256.

Palmquist, D. L., A. D. Beaulieu, and D. M. Barbano. 1993. Feed and animal factors influencing milk fat composition. J. Dairy Sci. $76: 1753-1771$

Rottman, L. W., Y. Ying, K. Zhou, P. A. Bartell, and K. J. Harvatine. 2014. The daily rhythm of milk synthesis is dependent on the timing of feed intake in dairy cows. Physiol. Rep. 2:e12049.

Sova, A. D., S. J. LeBlanc, B. W. McBride, and T. J. DeVries. 2013 Associations between farm-level feeding management practices, feed sorting, and milk production in freestall dairy farms. J. Dairy Sci. 96:4759-4770.

Stoffel, C. M., P. M. Crump, and L. E. Armentano. 2015. Effect of dietary fatty acid supplements, varying in fatty acid composition, on milk fat secretion in dairy cattle fed diets supplemented to less than 3\% total fatty acid. J. Dairy Sci. 98:431-442.

Toral, P. G., L. Bernard, Y. Chilliard, and F. Glasser. 2013. Short communication: Diet-induced variations in milk fatty acid composition have minor effects on the estimated melting point of milk fat in cows, goats, and ewes: Insights from a meta-analysis. J. Dairy Sci. 96:1232-1236.

US Department of Agriculture. 2015. Northeast Order Uniform Price for 2015: Monthly Price Releases. Accessed Apr. 8, 2016. http:// www.fmmone.com/Price_Announcements/Class_Component/ Past_Years/CP2015.pdf.

von Keyserlingk, M. A. G., A. Barrientos, K. Ito, E. Galo, and D. M. Weary. 2012. Benchmarking cow comfort on North American freestall dairies: Lameness, leg injuries, lying time, facility design, and management for high-producing Holstein dairy cows. J. Dairy Sci. 95:7399-7408.

Wojciechowski, K. L., and D. M. Barbano. 2016. Prediction of fatty acid chain length and unsaturation of milk fat by mid-infrared milk analysis. J. Dairy Sci. 99:8561-8570.

Wojciechowski, K. L., C. Melilli, and D. M. Barbano. 2016. A proficiency test system to improve performance of milk analysis methods and produce reference values for component calibration samples for infrared milk analysis. J. Dairy Sci. 99:6808-6827.

Woolpert, M. E., H. M. Dann, K. W. Cotanch, C. Melilli, L. E. Chase, R. J. Grant, and D. M. Barbano. 2016. Management, nutrition, and lactation performance are related to bulk tank milk de novo fatty acid concentration on Northeastern US dairy farms. J. Dairy Sci. 99:8486-8497. 